\title{
Dry-powder formulations of non-covalent protein complexes with linear or miktoarm copolymers for pulmonary delivery
}

Alejandro Nieto-Orellana ${ }^{a}$, David Coghlan ${ }^{b}$, Malcolm Rothery ${ }^{b}$, Franco H Falcone ${ }^{a}$, Cynthia Bosquillon $^{a}$, Nick Childerhouse ${ }^{b}$, Giuseppe Mantovani ${ }^{a *}$ and Snow Stolnik ${ }^{a *}$

${ }^{\text {a }}$ School of Pharmacy, University of Nottingham, Nottingham, United Kingdom.

${ }^{\mathrm{b}}$ Vectura Group plc, Chippenham, United Kingdom.

*Corresponding author: e-mail: snow.stolnik@nottingham.ac.uk and giuseppe.mantovani@nottingham.ac.uk, Fax: +44 (0)115 9515122; Tel: +44 (0)0115 8466074

KEYWORDS: dry powder, pulmonary delivery, polymer-protein complexes, spraydrying, protein delivery, non-covalent complexes. 


\begin{abstract}
Pulmonary delivery of protein therapeutics has considerable clinical potential for treating both local and systemic diseases. However, poor protein conformational stability, immunogenicity and protein degradation by proteolytic enzymes in the lung are major challenges to overcome for the development of effective therapeutics. To address these, a family of structurally related copolymers comprising polyethylene glycol, $\mathrm{mPEG}_{2 \mathrm{k}}$, and poly(glutamic acid) with linear A$\mathrm{B}\left(\mathrm{mPEG}_{2 \mathrm{k}}\right.$-lin-GA) and miktoarm A-B $3\left(\mathrm{mPEG}_{2 \mathrm{k}}-m i k-(\mathrm{GA})_{3}\right)$ macromolecular architectures was investigated as potential protein stabilisers. These copolymers form non-covalent nanocomplexes with a model protein (lysozyme) which can be formulated into dry powders by spray-drying using common aerosol excipients (mannitol, trehalose and leucine). Powder formulations with excellent aerodynamic properties (fine particle fraction of up to $68 \%$ ) were obtained with particle size $\left(\mathrm{D}_{50}\right)$ in the $2.5 \mu \mathrm{m}$ range, low moisture content $(<5 \%)$, and high glass transitions temperatures, i.e. formulation attributes all suitable for inhalation application. In aqueous medium, dry powders rapidly disintegrated into the original polymer-protein nanocomplexes which provided protection towards proteolytic degradation. Taken together, the present study shows that dry powders based on ( $\mathrm{mPEG}_{2 \mathrm{k}}$-polyGA)-protein nanocomplexes possess potentials as an inhalation delivery system.
\end{abstract}




\section{Introduction}

In recent years, pulmonary drug delivery has received increasing attention due to the physiological characteristics of the respiratory system which allows local, but also systemic, therapies (Scheuch et al., 2006). With large surface area and avoidance of first-pass metabolism, pulmonary delivery has become a very attractive strategy for the delivery of new therapeutic agents, especially for peptides and proteins (Hussain et al., 2004; Malik et al., 2007). Despite these advantages, challenges associated with the formulation of inhaled native proteins and their direct delivery to the lung epithelium (Dailey et al., 2003) - including poor bioavailability, side effects, denaturation/instability and frequent inability to cross the epithelial physiological barrier - still exist (Klingler et al., 2009; Niven, 1995; Nyambura et al., 2009; Umashankar et al., 2010). In vivo lung clearing mechanisms of biotherapeutics include mucociliary and macrophage clearance, and degradation by lung proteases (Depreter et al., 2013). To address the latter, co-administration of exogenous protease inhibitors has been investigated, although cytotoxicity of some inhibitors (Park et al., 2007), and the possibility of unbalancing the protease/anti-protease equilibrium, with consequent alteration of airway surface liquid homeostasis (Garcia-Verdugo et al., 2010), can be a significant issue (Depreter et al., 2013). Thus, alternative routes able to complement current approaches are still much needed.

Polymeric nanoparticles have been investigated as potential formulations for pulmonary delivery of protein therapeutics (Bailey and Berkland, 2009), as they can offer protection from degradation both during storage and in vivo, can enhance transepithelial transport (Fowler et al., 2013a; Fowler et al., 2013b), and can reduce immunogenicity (Soppimath et al., 2001; Sung et al., 2007). However, polymeric materials with slow degradation profiles can potentially lead to pulmonary accumulation of nanoparticles, especially when daily administration is needed 
(Dunne et al., 2000), resulting in long-term toxicity in the lungs (Armstrong et al., 1996; Sivadas et al., 2008). Within this context, formulations based on drug complexes with polymeric materials that possess relatively shorter life-time in the lung, such as 'soluble' polymer-protein nanocomplexes, could overcome pulmonary accumulation issues while still providing protection and opportunities for cellular targeting and intra/transcellular transport. These can be prepared by mixing of protein and polymeric solutions to form complexes based on non-covalent molecular interactions that can be reversed under specific conditions (NietoOrellana et al., 2017) to release the protein therapeutic in vivo.

Protein nanocomplexes are commonly formulated in aqueous solutions. However, major protein degradation mechanisms including de-amidations and hydrolysis are 'water-mediated' (Depreter et al., 2013). Moreover, aqueous solutions and suspensions are susceptible to microbial growth, which can promote the contamination of pulmonary devices, especially those used for chronic treatments (Jarvis et al., 2014). Within this context, dry powders are an attractive alternative for the delivery of protein therapeutics to the lungs. Spray-drying is the most common technique utilised for the production of inhalable dry powder formulations of protein therapeutics (Maltesen et al., 2008; You et al., 2007). For efficient deposition in the lungs, particles must possess specific particle size, density, and shape - collectively defined as the aerodynamic diameter (Carvalho et al., 2011). However, spray-drying of aqueous solution of proteins can induce aggregation and/or loss of activity (Adler and Lee, 1999; Haque and Adhikari, 2015; Maury et al., 2005a; Tzannis and Prestrelski, 1999), which must be minimised through ad hoc formulation strategies. Most of the currently available commercial inhalation products use lactose as a carrier material (Pilcer et al., 2012). However, lactose may not be always suitable for formulations of actives that contain primary amino groups, such as peptides and proteins, because of a range of potential side-reaction occurring at the sugar reducing end 
(e.g. Maillard reaction), especially when the formulation process requires higher temperatures (Littringer et al., 2012a). Therefore, non-reducing sugars such as mannitol and trehalose have been investigated as potential alternatives (Littringer et al., 2012b; Maury et al., 2005a).

Recently, we reported that $\mathrm{mPEG}_{2 \mathrm{k}}$-poly(glutamic acid) copolymers with linear A-B (mPEG $2 \mathrm{k}^{-}$ lin-polyGA), and miktoarm A-B $\left.3\left(\mathrm{mPEG}_{2 \mathrm{k}}-m i k \text {-(polyGA)}\right)_{3}\right)$ architectures can be successfully utilized in reversible protein complexation (Nieto-Orellana et al., 2017). At physiological pH, the polyGA block(s) possess multiple copies of anionic carboxylate units which can complex positively charged amino acids at the surface of protein molecules (lysozyme was utilized as a model protein). In the present study, we aimed to fabricate these non-covalent polymer-protein nanocomplexes into inhalable spray-dried powders suitable for pulmonary delivery. The aerosolisation properties of dry powders formulated from polymer-protein nanocomplexes were investigated using trehalose, mannitol and/or leucine as typical aerosol excipients. Leucine as a dispersion enhancer plays a crucial role in promoting de-aggregation of microparticles by limiting interparticulate forces, while trehalose and mannitol are common protective agents for biopharmaceuticals during both formulation and storage (Bakaltcheva et al., 2007; Hulse et al., 2008; Jin et al., 2010; Kibbe and Association, 2000; Maa et al., 1997; Ogain et al., 2011; Schüle et al., 2007; Torrado and Torrado, 2002). The lung possesses a wide range of pulmonary peptidases that function as specific clearance mechanisms for proteins and peptides, resulting in possible degradation/inactivation of applied biotherapeutic protein. Here, we show that the protein-polymer nanocomplexes liberated from dry powder formulations in aqueous medium possess a crucial ability to preserve protein activity.

\section{Materials and methods.}

\subsection{Materials.}


Sodium phosphate dibasic $(99.9 \%)$, sodium phosphate monobasic dehydrate $(\geq 99.0 \%)$, phosphoric acid, Micrococcus lisodeikticus lyophilised cells, trypsin from bovine pancreas,

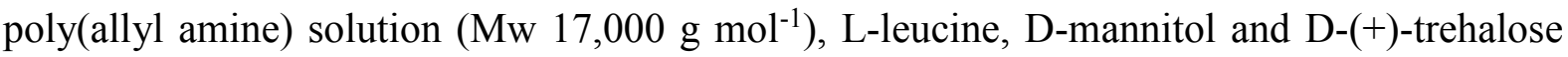
dihydrate were purchased from Sigma Aldrich. Lysozyme molecular biology grade and BCA protein assay kit was supplied by AppliChem and ThermoFisher Technologies, respectively.

Linear $\mathrm{mPEG}_{2 \mathrm{k}}$-lin-GA 10 and $\mathrm{mPEG}_{2 \mathrm{k}}-$ lin- $\mathrm{GA}_{30}$; and miktoarm $\mathrm{mPEG}_{2 \mathrm{k}}-$ mik-(GA 10$)_{3}$ and $\mathrm{mPEG}_{2 \mathrm{k}}-m i k-\left(\mathrm{GA}_{30}\right)_{3}$ copolymers were synthetized by ring-opening polymerization of $\gamma-$ benzyl-L-glutamate $\mathrm{N}$-carboxyanhydride (NCA) monomer from appropriate $\omega$-amino poly(ethylene glycol)s, as previously described (Nieto-Orellana et al., 2017).

\subsection{Preparation of polymer-protein nanocomplexes.}

$\left(\mathrm{mPEG}_{2 \mathrm{k}}\right.$-polyGA)-lysozyme nanocomplexes were prepared at relative molar charge ratio $r=$ 2.5 where $r$ is the charge ratio between the number of glutamic acid residues present in the copolymer (negatively charged at physiological $\mathrm{pH}$ ) and that of protein lysine and arginine residues (17 in total per protein molecule positively charged at physiological $\mathrm{pH}$ ) of lysozyme. Polymers and protein were separately dissolved in phosphate buffer $(\mathrm{PB}, 10 \mathrm{mM}, \mathrm{pH} 7.4)$ and appropriate aliquots were mixed to achieve $r=2.5$ (Nieto-Orellana et al., 2017).

\subsection{Preparation of the liquid feed for spray-drying.}

To prepare 'liquid feed' for spray drying, $37.5 \mathrm{~mL}$ of nanocomplex suspension $\left(2 \mathrm{mg} \mathrm{mL}^{-1}\right)$ was added to $37.5 \mathrm{~mL}$ of the excipients solution in deionized water, as summarized in ESI, Table S1. The final total solid content of the suspension was always kept constant at $1 \%(w / v)$. The suspension was gently stirred on a roller for $30 \mathrm{~min}$ at room temperature prior to spraydrying. The components of the resulting dry powders were as follows: $0-10 \%(w / w)$ 
nanocomplexes or 5\% (w/w) lysozyme, 0-10\% $(w / w)$ leucine, $6.6 \%(w / w)$ phosphate buffer salts, and trehalose or mannitol as bulking agents (up to $100 \%(w / w)$ ). For example, for the Up to $100 \%$ Trehalose formulations (Table 1), the following compositions apply:

- control formulation containing no lysozyme: 0\% nanocomplexes $(w / w), 6.6 \%(w / w)$ phosphate buffer salts, $93.4 \%(w / w)$ trehalose.

- control formulation containing un-complexed free lysozyme (dry powder formulation that contains lysozyme only, with no copolymer added): $0 \%$ nanocomplexes $(w / w), 5 \%$ free lysozyme $(w / w), 6.6 \%(w / w)$ phosphate buffer salts, $88.4 \%(w / w)$ trehalose

- formulations containing $\left[\mathrm{mPEG}_{2 \mathrm{k}}-(\operatorname{poly}(\right.$ glutamic acid))-lysozyme] nanocomplexes: $10 \%$ nanocomplexes $(w / w), 6.6 \%(w / w)$ phosphate buffer salts, $83.4 \%(w / w)$ trehalose.

\subsection{Spray-drying conditions.}

Laboratory scale spray-drying equipment developed by Vectura Group plc (Chippenham, United Kingdom) was used to produce the dry powders. The optimal operating conditions were: total solids content: $1 \%(w / v)$, atomization air flow rate: $15 \mathrm{~L} \mathrm{~min}^{-1}$, atomization air pressure: 2.5 bar, air outlet temperature: $65^{\circ} \mathrm{C}$, liquid feed flow rate: $2.5 \mathrm{~mL} \mathrm{~min}{ }^{-1}$, drying air flow rate $17 \mathrm{~kg} \mathrm{~h}^{-1}$ and drying gas pressure: 2.0 bar. The resulting dry powder formulations were handled and stored at low humidity $(<30 \%)$.

The yield was calculated as the ratio between the weight of solids collected after spray-drying and that of the initial amount of ingredients used to prepare the aqueous solutions, expressed as a percentage $(\%)$.

\subsection{Dry powder characterization}

\subsubsection{Particle size distribution and morphology}


Particle size distribution of sprayed samples was measured by laser diffraction (ASPIROS Sympatec, Clausthal-Zellerfeld, Germany). Powders were dispersed through the measurement zone under a dispersion pressure of 2.0 bar using the $\mathrm{R} 2$ lens. The measurements were performed in triplicate. Size is reported as mean volumetric diameter $\left(\mathrm{D}_{50}\right)$ and distribution width is presented as span. Span index is calculated as follows:

$$
\operatorname{Span}=\frac{\mathrm{D}_{90}-\mathrm{D}_{10}}{\mathrm{D}_{50}}
$$

where $D_{10}, D_{50}$ and $D_{90}$ are the diameters below which $10 \%, 50 \%$ and $90 \%$ of the particle population lie, respectively. The morphology of the particles was visualized by scanning electron microscopy (SEM). The samples were mounted onto aluminum stubs and sputter coated $(20 \mathrm{~nm})$ with gold/palladium target using a Quorum Q15 TES coating unit. The samples were viewed using a Hitachi S3000H Scanning Electron Microscope with an accelerating voltage of $10 \mathrm{kV}$.

\subsubsection{Moisture content}

Particle moisture content was measured immediately after spray-drying by thermogravimetric analysis under non-oxidizing conditions (TGA 4000). For the analysis, 10-20 mg of powder were heated from $20^{\circ} \mathrm{C}$ to $160{ }^{\circ} \mathrm{C}$ at $10{ }^{\circ} \mathrm{C} \mathrm{min}-1$ and maintained at the final temperature for 5 min before measurement.

\subsubsection{Protein incorporation efficiencies}

The amount of protein encapsulated in the dry powders was evaluated by bicinchoninic acid (BCA) assay. Dry powders were first incubated in PB for $1 \mathrm{~h}$ under gentle stirring, at room temperature - at a theoretical protein concentration of $15-25 \mu \mathrm{g} \mathrm{mL} L^{-1}$ (mass of protein assuming $100 \%$ protein incorporation). Then $150 \mu \mathrm{L}$ of particle samples and $150 \mu \mathrm{L}$ of BCA solution 
prepared as described by the manufacturer (BCA protein assay kit, ThermoFisher Technologies) were mixed and heated at $56^{\circ} \mathrm{C}$ for $60 \mathrm{~min}$. Once cooled down to $25^{\circ} \mathrm{C}$, the absorbance was measured at $\lambda=562 \mathrm{~nm}$ using a micro-plate reader (SpectraMax M2). All the absorbance values were corrected by subtracting the values measured for relevant blank samples. Each measurement was performed in quadruplicate. The protein encapsulation (\%) was calculated as a percentage between the amount of protein in the dry powder, determined from a calibration curve, and the amount of protein present in the liquid feed.

\subsubsection{Differential scanning calorimetry (DSC)}

Samples were prepared in closed aluminum pans. 2-3 mg of powders was heated from $10^{\circ} \mathrm{C}$ to $60^{\circ} \mathrm{C}$ at $10^{\circ} \mathrm{C} \min ^{-1}$ and then cooled down to $10^{\circ} \mathrm{C}$. This process was then repeated 3 times, increasing the temperature to $130^{\circ} \mathrm{C}, 140^{\circ} \mathrm{C}$ and $230^{\circ} \mathrm{C}$, respectively. Glass transition $\left(\mathrm{T}_{\mathrm{g}}\right)$, heat capacity $(\Delta \mathrm{Cp})$, melting point $\left(\mathrm{T}_{\mathrm{m}}\right)$ and enthalpy of melting $\left(\Delta \mathrm{H}_{\mathrm{m}}\right)$ were derived from the resulting thermograms.

\subsubsection{In vitro pulmonary deposition.}

The aerodynamic properties of dry powders were assessed using a fast screening impactor (FSI, Copley Scientific). A standard dispersion procedure was conducted for $4 \mathrm{~s}$ at an air flow rate of $60 \mathrm{~L} \mathrm{~min}^{-1}$. The cut-off aerodynamic diameter was $5 \mu \mathrm{m}$. An amount of $12 \pm 1 \mathrm{mg}$ of powder was loaded into blisters and aerosolised using a proprietary unit dose DPI (Vectura, UK). The emitted dose (ED) was calculated by accurately weighing the blister before and after aerosolization. Particles with an aerodynamic diameter lower than $5 \mu \mathrm{m}$ were deposited on a filter in the fine fraction collector. The filter was weighed before and after dispersion, in order to determine the fine particle fraction (FPF), which can be defined as the fraction (\%) of the emitted dose (ED) with an aerodynamic diameter below $5 \mu \mathrm{m}$. Each powder was tested in triplicate. 
To investigate whether the nanocomplexes could be recovered in their initial size from the dry powders, the latter samples were incubated in $\mathrm{PB}$ for 15 min under gentle stirring at room temperature at a protein concentration of $70 \mu \mathrm{g} \mathrm{mL}-1$ (as quantified by BCA assay). The hydrodynamic diameter of particles in such formed suspension was then measured by nanoparticle tracking analysis (NTA) using a Nanosight LM14. All measurements were performed at $25^{\circ} \mathrm{C}$. NTA 2.0 Build 127 software was used for data capturing and analysis. The samples were measured for $80 \mathrm{~s}$. Particle size distributions are represented here as normalized distributions where the particle size of the largest population is taken as $100 \%$.

\subsection{Lysozyme activity}

The enzymatic activity of lysozyme, was measured by a turbidimetric enzymatic assay where the decrease in optical density of a suspension of Micrococcus lysodeikticus lyophilized cells, a natural substrate for lysozyme, in PB was monitored (Tomita et al., 2010). Nanocomplexes or free lysozyme were extracted from the dry powders as described above and the protein concentration was adjusted to $37 \mu \mathrm{g} \mathrm{mL} \mathrm{L}^{-1}$ (as quantified by BCA assay). $10 \mathrm{mg}$ of lyophilized cells were added to $20 \mathrm{~mL}$ of PB. $300 \mu \mathrm{L}$ of this substrate suspension were added to $150 \mu \mathrm{L}$ of nanocomplexes suspension and the decrease in optical density (OD) was measured at $\lambda=460$ $\mathrm{nm}$ as a function of time, for $60 \mathrm{sec}$. The OD decay plots from 0 to $10 \mathrm{sec}$ were fitted to a linear equation and the enzymatic activities were then determined from the slope of the fitted line.

To recover lysozyme from the polymer nanocomplexes, in order to assess its residual enzymatic activity, $480 \mu \mathrm{g}$ of poly(allyl amine) competitive ligand were added to $2 \mathrm{~mL}$ of the nanocomplex suspension (corresponding to a lysozyme concentration of $37 \mu \mathrm{g} \mathrm{mL}^{-1}$ ) to sequester lysozyme from mPEG-polyGA complexes, and the mixture was maintained under very gentle stirring for $1 \mathrm{~h}$ at room temperature. The lysozyme activity in the resulting solution 
was then quantified as described above. Unprocessed, 'free' lysozyme was used as reference (100\% enzymatic activity). All enzymatic activity experiments were carried out in triplicate.

2.8 (mPEG-polyGA)-lysozyme complexes: stability against proteolytic degradation.

To assess the protein protection capability of the nanocomplexes against enzymatic degradation, these were first recovered from the dry powders as described above, the protein concentration adjusted to $37 \mu \mathrm{g} \mathrm{mL}^{-1}$ (as quantified by BCA assay) and $657 \mu \mathrm{g}$ of trypsin added to $4 \mathrm{~mL}$ of nanocomplex suspension. The mixture was kept at room temperature for $3 \mathrm{~h}$ under gentle stirring. $480 \mu \mathrm{g}$ of poly(allyl amine) was added to the mixture and gently stirred for $1 \mathrm{~h}$. Lysozyme activity was quantified as described above. All enzymatic activity experiments were carried out in triplicate.

\subsection{Statistical analysis}

Measurements were carried out in triplicate, unless otherwise stated. Values are given as means $\pm \mathrm{SD}$. The statistical significance of the results was assessed using one-way analysis of variance (ANOVA), Dunnet's multiple comparisons test.

\section{Results and Discussion}

\subsection{Formulation and characterization of (mPEG ${ }_{2 k}$-polyGA)-lysozyme dry powders}

In this work we used two A-B linear and two $\mathrm{A}-\mathrm{B}_{3}$ miktoarm copolymers of $\mathrm{mPEG}_{2 \mathrm{kDa}}$-polyGA recently developed, consisting of one $2.0 \mathrm{kDa}$ monomethoxy polyethylene glycol, $\left(\mathrm{mPEG}_{2 \mathrm{k}}\right)$, arm (A) and one, or three, respectively, poly(glutamic acid), poly(GA), branches (B) of variable chain length, which allow for complexation with positively charged amino acids within protein molecule (Figure 1). 


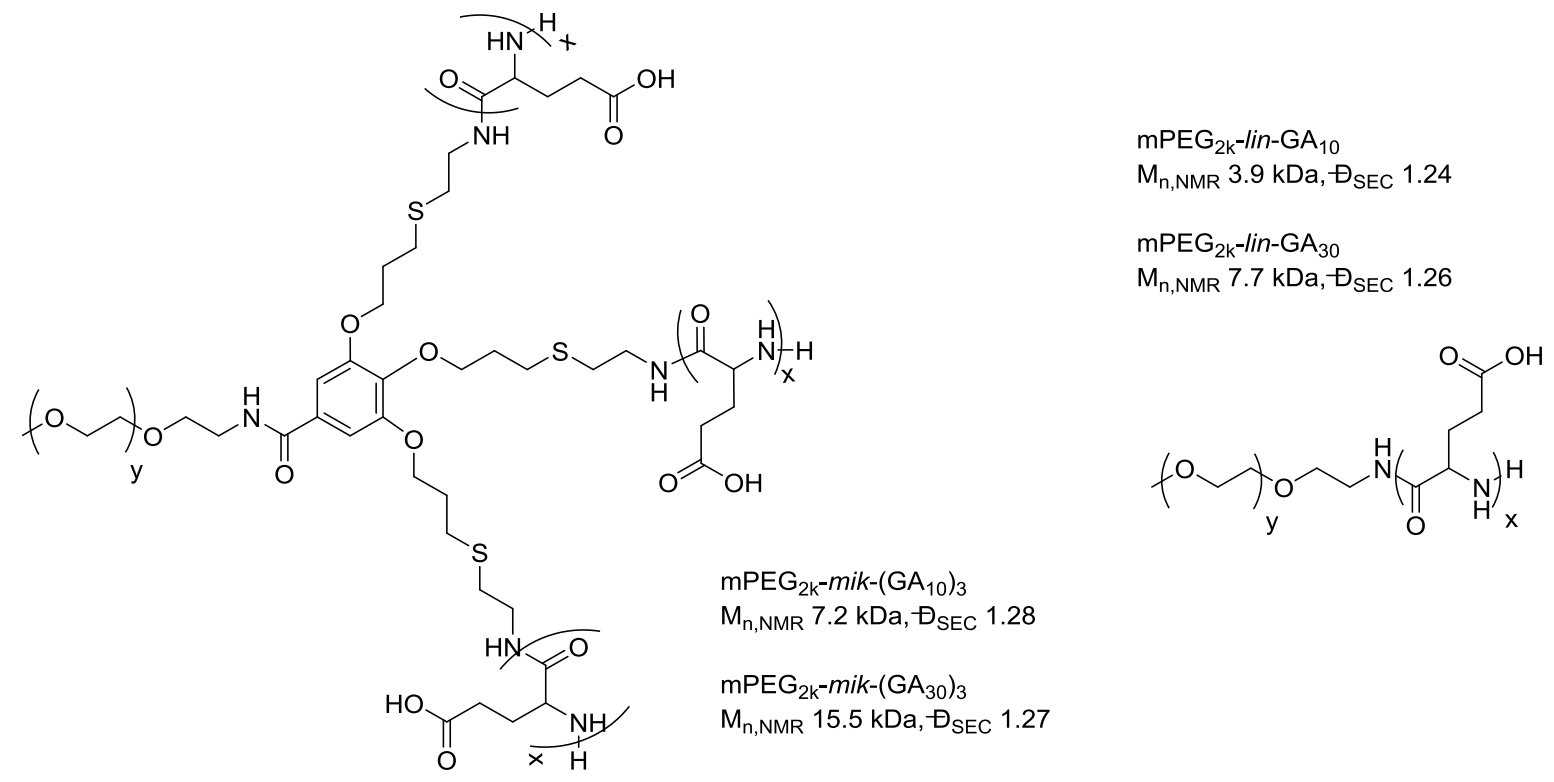

Figure 1. Chemical structure of miktoarm (left) and linear (right) $\mathrm{mPEG}_{2 \mathrm{k}}$-polyGA copolymers used in this work.

We previously demonstrated that biocompatible linear and miktoarm $\mathrm{mPEG}_{2 \mathrm{k}}$-polyGA copolymers were capable of non-covalent protein complexation in aqueous solution under appropriate conditions. We also showed that protein molecules were predominantly located in the "core" of these nano-assemblies and that protein integrity was not negatively affected by polymer complexation (Nieto-Orellana et al., 2017). Here, we further explored the therapeutic potential of this technology by investigating if ( $\mathrm{mPEG}_{2 \mathrm{k}}$-polyGA)-protein nanocomplexes can be efficiently formulated into inhalable spray-dried powders. The resulting formulations were characterised in terms of particle size, moisture content, thermal properties, encapsulation efficiency, aerodynamic properties, and protein protection to assess their suitability for inhalable dry powder formulations. Due to its 6 lysine and 11 arginine residues positively charged at physiological pH (Masuda et al., 2005) and an isoelectric point at pH 11.3 (Wetter and Deutsch, 1951), lysozyme was chosen as a representative positively charged protein which can be reversibly complexed with polyanionic polymer moiety. In a previous study, we have optimized the complexation conditions of lysozyme with $\mathrm{mPEG}_{2 \mathrm{k}}$-polyGA (Nieto-Orellana et al., 2017). That work was further expanded here to assess developability of the complexes for 
formulation into inhalation dry powders by spray-drying. Additionally, the biological i.e. enzymatic activity of lysozyme can be routinely assessed through an established assay, making this protein substrate particularly suitable for monitoring potential loss of functional activity following processing by spray-drying.

While investigation of metabolism (biodegradability) of the $\mathrm{mPEG}_{2 \mathrm{k}}$-polyGA materials in the lung is beyond the scope of the present study, these polymers were designed to be degradable in vivo. Poly(glutamic acid) can be hydrolysed into its aminoacid constituents by a range of proteases, particularly cysteine proteases, including cathepsin B and cathepsin L (Melancon et al., 2007). Cathepsin B is secreted by a number of pulmonary cells, and has been found in both healthy and diseased lung tissues (Werle et al., 1994; Heidtmann et al., 1997; Křepela et al., 1995). Conversely, cathepsin L is stably expressed in bronchiolar epithelial cells (Okudela et al., 2016). One can expect that, once the poly(glutamic acid) is enzymatically hydrolysed, the short residual PEG of 2000 Da molecular weight would be cleared from the lungs. Indeed, Gursahani et al have shown that short PEGs $(<2000 \mathrm{Da})$ were efficiently cleared from rat lungs within 48 h (Gursahani et al., 2009).

Polymer-protein nanocomplexes were first assembled by mixing $\mathrm{mPEG}_{2 \mathrm{k}}$-polyGA copolymers and lysozyme at relative molar charge ratio of 2.5:1 (defined as the ratio between the number of glutamic acid residues present in the copolymer and negatively charged at physiological $\mathrm{pH}$, and the protein lysine and arginine residues, respectively) in $10 \mathrm{mM}$ phosphate buffer, $\mathrm{pH}$ 7.4. The toxicological profile of free $\mathrm{mPEG}_{2 \mathrm{k}}$-polyGA copolymers and their complexes with lysozyme, was assessed in the human alveolar (A549) and human bronchial (Calu-3) epithelial cell lines by both metabolic activity (MTS) and lactate dehydrogenase (LDH) assays after a 4 or 24 hour treatment. Both the copolymers alone, and the corresponding lysozyme nanocomplexes were found non-cytotoxic within the range of polymer concentrations investigated (0-200 $\mu \mathrm{g} \mathrm{mL} \mathrm{m}^{-1}$, Figure S3 \& S4, Supporting Information). The resulting 
nanocomplexes were then formulated into dry powders by spray drying - using typical aerosol excipients trehalose or mannitol and leucine - to form potentially inhalable dry powder of micron-size range particles. Trehalose was used as a bulk agent as it is a well-established stabiliser for bio-molecules formulations that are sensitive to loss of activity and structural integrity during desiccation. The rigid amorphous matrix created by trehalose below its glass transition temperature is believed to stabilise biological molecules by reducing rate of degradation reactions (Hulse et al., 2008; Jin et al., 2010; Maa et al., 1997; Ogain et al., 2011). Furthermore, amorphous trehalose has been suggested to act as a substitute for water in the formation of hydrogen bonds with protein molecules, thus stabilising their three-dimensional structure in the dry state (Chang and Pikal, 2009; Vehring, 2008; Weers et al., 2007). In contrast, and due to its relatively low $\mathrm{T}_{\mathrm{g}}\left(11^{\circ} \mathrm{C}\right)$, mannitol tends to recrystallise during spraydrying (Weers et al., 2007). It therefore has a much lower protein stabilising ability, although its inherent physical stability is greater (Bakaltcheva et al., 2007; Kibbe and Association, 2000; Schüle et al., 2007; Torrado and Torrado, 2002). Leucine, a hydrophobic amino acid, is a wellestablished dispersion enhancer which would normally be located on the surface of micronsized particles (typically $<10 \mu \mathrm{m}$ ) after spray-drying (Li et al., 2003; Vehring, 2008). In this way, it limits the interaction forces between particles and facilitates their dispersion and aerosolisation (Li et al., 2003; Vehring, 2008). Four formulations: trehalose, trehalose $+10 \%$ $(w / w)$ leucine, mannitol, and mannitol $+10 \%(w / w)$ leucine, each containing either none or $10 \%(w / w)$ of nanocomplexes or 5\% (w/w) uncomplexed lysozyme - were tested in this study (Table1).

The presence of ( $\mathrm{mPEG}_{2 \mathrm{k}}$-polyGA)-lysozyme nanocomplexes, did not negatively affect the spray-drying yields of formulations containing trehalose+leucine, compared to control dry powders prepared with $(5 \% \mathrm{w} / w)$ of 'free' uncomplexed lysozyme model protein (Table 1). The nanocomplexes content in the dry powder formulations was kept constant at $10 \% \mathrm{w} / \mathrm{w}$, 
however, as the $\mathrm{mPEG}_{2 \mathrm{k}}$-polyGA polymers utilised to complex lysozyme had different molecular weights, the amount in weight of lysozyme varied, from 4.9-6.6 \%, for each formulation prepared (ESI, Table S1). Thus, for the control dry powders containing uncomplexed free lysozyme, a $5 \% w / w$ lysozyme content, as a representative content in the nanocomplexes formulations, was chosen. Furthermore, the use of nanocomplexes significantly increased the yield of mannitol+leucine formulations from $30.9 \%$ using 'free' lysozyme, to $60.9 \%$ for the nanocomplexes samples (Table 1). Values between 40 and $60 \%$ yield are usually considered as satisfactory for lab-scale spray-dryers (Islam and Langrish, 2010). For samples formulated without leucine, lower and more variable spray-drying yields were observed using both 'free' lysozyme and polymer-lysozyme nanocomplexes. It should be noted that formulations prepared with mannitol in absence of leucine were obtained with a very low yield and were not characterised further. No significant effect of ( $\mathrm{mPEG}_{2 \mathrm{k}}$-polyGA) polymer size and topology on final yield was observed.

Similarly, the presence of polymer-protein nanocomplexes in spray-dried powders had no detrimental effect on their particle size distribution (Table 1). For leucine-containing spray dried powders, median volumetric diameters $\left(\mathrm{D}_{50}\right)$ were found to be in the 2-3 $\mu \mathrm{m}$ range, which is generally considered optimal for inhalation purposes (Labiris and Dolovich, 2003). The particle size distribution width (span values) of those powders was lower than 2, a value typically attributed to narrow particle size distributions (Palazzo et al., 2013). Overall, the use of leucine helped in achieving satisfactory yields and particle size distributions suitable for inhalation dry powders.

As described previously for these materials (Pourshahab et al., 2011), SEM analysis revealed that trehalose+leucine containing dry powders generally possessed a spherical shape and 
relatively smooth surface (Figure 2, panels B and E), whilst particles from mannitol+leucine had a rougher surface (Figure 2, images A and D), likely as a consequence of the crystalline nature of mannitol. The presence of leucine was found to be key to obtaining a well formed spherical morphology of the spray-dried powders (Figures 2 and S2). It is important to note that the presence of polymer-protein nanocomplexes had no noticeable negative impact on the morphology of the spray-dried powders (Figure 2, images A vs. D, and B vs. E).

Table 1. Effect of formulation compositions on spray-drying yield, and particle size and span values.

\begin{tabular}{|c|c|c|c|c|}
\hline $\begin{array}{l}\text { Excipients } \\
(w / w)\end{array}$ & $\begin{array}{c}\text { Nanocomplexes } \\
(w / w)\end{array}$ & Yield (\%) ${ }^{a}$ & $D_{50}(\mu \mathrm{m})^{b}$ & Spanc \\
\hline \multirow[t]{6}{*}{ Up to $100 \%$ Trehalose } & no lysozyme (control) & $41.2^{\mathrm{d}}$ & $1.70 \pm 0.01$ & $1.95 \pm 0.02$ \\
\hline & $5 \%$ Free lysozyme & 36.0 & $1.99^{\mathrm{e}}$ & $1.78^{\mathrm{e}}$ \\
\hline & $10 \%\left(m E_{2 k}-\right.$ lin-GA 10$)$-Lysozyme & 15.3 & $2.48^{d}$ & $28.16^{d}$ \\
\hline & $10 \%\left(\mathrm{mPEG}_{2 \mathrm{k}}\right.$-lin-GA $\left.\mathrm{G}_{30}\right)$-Lysozyme & 18.3 & $1.49^{\mathrm{e}}$ & $1.17^{\mathrm{e}}$ \\
\hline & $10 \%\left(\mathrm{mPEG}_{2 \mathrm{k}}-\right.$ mik-$\left.\left(\mathrm{GA}_{10}\right)_{3}\right)$-Lysozyme & 20.9 & $1.45^{\mathrm{e}}$ & $1.81^{\mathrm{e}}$ \\
\hline & $10 \%\left(\mathrm{mPEG}_{2 \mathrm{k}}-m i k-\left(\mathrm{GA}_{30}\right)_{3}\right)$-Lysozyme & 21.5 & $1.30^{\mathrm{e}}$ & $1.46^{\mathrm{e}}$ \\
\hline \multirow{7}{*}{$\begin{array}{l}\text { Up to } 100 \% \text { Trehalose } \\
+10 \% \text { Leucine }\end{array}$} & no lysozyme (control) & $76.4^{d}$ & $2.50 \pm 0.02$ & $1.77 \pm 0.01$ \\
\hline & & & & \\
\hline & 5\% Free lysozyme & 57.8 & $2.37 \pm 0.03$ & $1.74 \pm 0.02$ \\
\hline & $10 \%\left(\mathrm{mPEG}_{2 \mathrm{k}}-\right.$ lin-GA 10$)$-Lysozyme & 55.6 & $2.43 \pm 0.06$ & $1.59 \pm 0.02$ \\
\hline & $10 \%\left(\mathrm{mPEG}_{2 \mathrm{k}}\right.$-lin-GA $\left.\mathrm{G}_{30}\right)$-Lysozyme & 49.7 & $2.45 \pm 0.02$ & $1.61 \pm 0.01$ \\
\hline & $10 \%\left(\mathrm{mPEG}_{2 \mathrm{k}}-m i k-\left(\mathrm{GA}_{10}\right)_{3}\right)$-Lysozyme & 53.8 & $2.32 \pm 0.07$ & $1.67 \pm 0.04$ \\
\hline & $10 \%\left(\mathrm{mPEG}_{2 \mathrm{k}}-\mathrm{mik}-\left(\mathrm{GA}_{30}\right)_{3}\right)$-Lysozyme & 62.4 & $2.30 \pm 0.02$ & $1.73 \pm 0.02$ \\
\hline \multirow[t]{6}{*}{ Up to $100 \%$ Mannitol } & no lysozyme (control) & $69.8^{d}$ & $2.29 \pm 0.03$ & $1.88 \pm 0.01$ \\
\hline & 5\% Free lysozyme & 11.5 & $5.79^{e}$ & $1.82^{\mathrm{e}}$ \\
\hline & $10 \%\left(\mathrm{mPEG}_{2 \mathrm{k}}\right.$-lin-GA 10 )-Lysozyme & 4.0 & - & - \\
\hline & $10 \%\left(\mathrm{mPEG}_{2 \mathrm{k}}\right.$-lin-GA $\left.\mathrm{G}_{30}\right)$-Lysozyme & 20.7 & $6.61^{d}$ & $1.70^{\mathrm{d}}$ \\
\hline & $10 \%\left(\mathrm{mPEG}_{2 \mathrm{k}}-\right.$ mik-$\left.\left(\mathrm{GA}_{10}\right)_{3}\right)$-Lysozyme & 5.7 & - & - \\
\hline & $10 \%\left(\mathrm{mPEG}_{2 \mathrm{k}}-\right.$ mik-$\left.\left(\mathrm{GA}_{30}\right)_{3}\right)$-Lysozyme & 8.6 & - & - \\
\hline \multirow{3}{*}{$\begin{array}{l}\text { Up to } 100 \% \text { Mannitol } \\
+10 \% \text { Leucine }\end{array}$} & no lysozyme (control) & $78.0^{\mathrm{d}}$ & $2.45 \pm 0.06$ & $1.80 \pm 0.05$ \\
\hline & 5\% Free lysozyme & 30.9 & $2.73 \pm 0.04$ & $1.75 \pm 0.01$ \\
\hline & $10 \%\left(m E_{2 k}-\right.$ lin-GA 10 )-Lysozyme & 54.3 & $2.62 \pm 0.04$ & $1.94 \pm 0.02$ \\
\hline
\end{tabular}




\begin{tabular}{|c|c|c|c|}
\hline $10 \%\left(\mathrm{mPEG}_{2 \mathrm{k}}\right.$-lin-GA $\mathrm{A}_{30}$ )-Lysozyme & 60.9 & $2.66 \pm 0.14$ & $1.74 \pm 0.03$ \\
\hline $10 \%\left(\mathrm{mPEG}_{2 \mathrm{k}}-m i k-\left(\mathrm{GA}_{10}\right)_{3}\right)$-Lysozyme & 52.0 & $2.50 \pm 0.01$ & $1.70 \pm 0.01$ \\
\hline $10 \%\left(\mathrm{mPEG}_{2 \mathrm{k}}-\right.$ mik-$\left.\left(\mathrm{GA}_{30}\right)_{3}\right)$-Lysozyme & 48.6 & $2.58 \pm 0.06$ & $1.63 \pm 0.02$ \\
\hline
\end{tabular}

All formulations also contained 6.6\% (w/w) phosphate buffer salts. Experiments were carried out in triplicate unless specified otherwise.

a Yield is calculated from the amount of solid mass obtained from the spray-drying divided by the total amount of solid ingredients delivered to the chamber of the spray-drier, expressed as a percentage. ${ }^{\mathrm{b}}$ Particle size, $\mathrm{D}_{50}$, denotes the size below which $50 \%$ of the particle population lie. ${ }^{c}$ Span=(D90-D $\left.\mathrm{D}_{10}\right) / \mathrm{D}_{50}$, where $\mathrm{D}_{10}, \mathrm{D}_{50}$ and $\mathrm{D}_{90}$ are the diameters below which $10 \%, 50 \%$ and $90 \%$ of the particle population lie, respectively. ${ }^{\mathrm{d}}$ Protein-free dry powder formulations were prepared on a larger (two-fold) scale which for laboratory scale spray-drying can lead to higher yields. ${ }^{e}$ Data obtained from single or duplicate measurements. ' - 'indicates that no measurement was performed due to the low amount of material obtained after spray-drying.
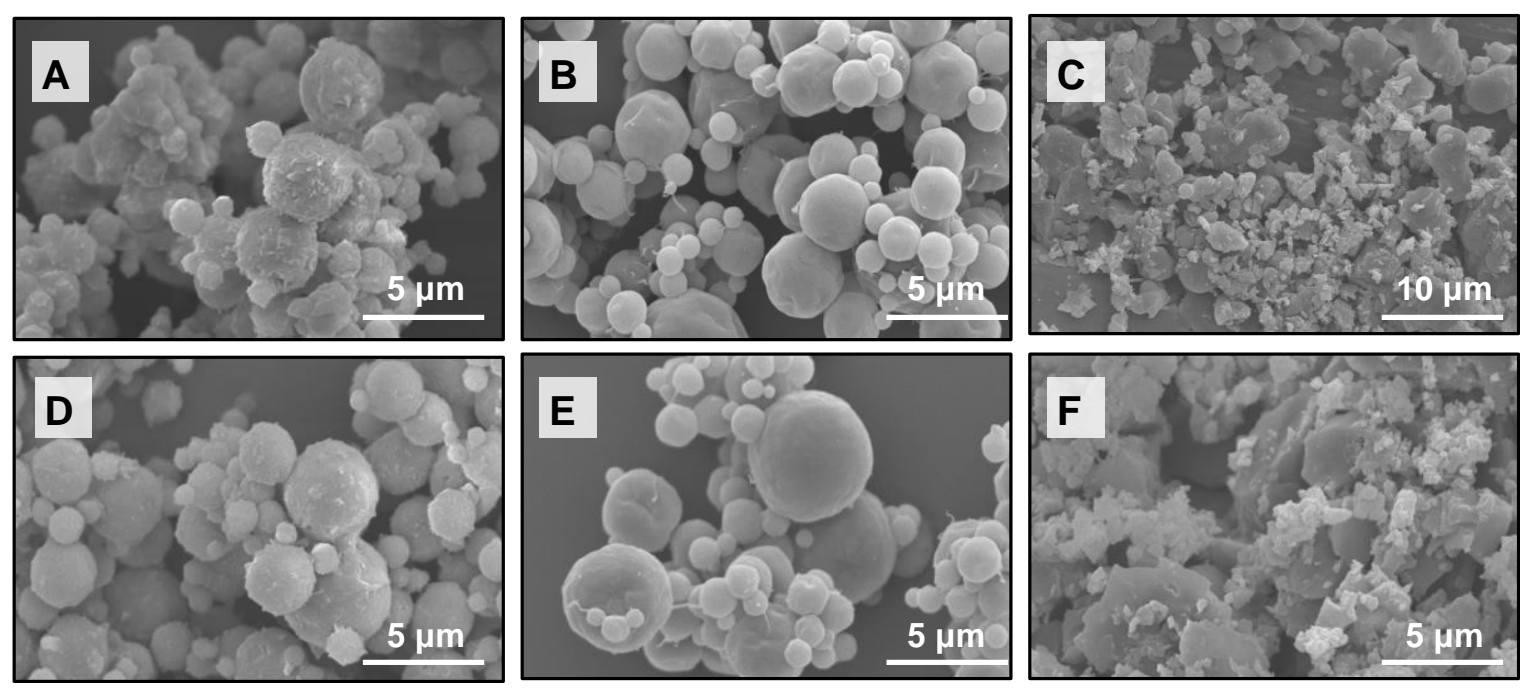

Figure 2. Representative scanning electron microscopy (SEM) images of dry powders. Samples contain 'uncomplexed lysozyme' (A, B and C), and lysozyme-( $\left.\mathrm{mPEG}_{2 \mathrm{k}}-m i k-\left(\mathrm{GA}_{30}\right)_{3}\right)$ nanocomplexes $(\mathrm{D}, \mathrm{E}$ and $\mathrm{F})$. 'Uncomplexed lysozyme' refers to dry powder formulations that contain lysozyme only, with no copolymer added. Excipients: mannitol + leucine (A, D), trehalose + leucine (B, E), or mannitol (C, F). All formulations also contain $6.6 \%(w / w)$ phosphate buffer salts.

Polymer-protein nanocomplexes were found to be efficiently incorporated into dry powders with encapsulation efficiencies between 80 and 100\% (Figure 3). The excipients or the complexing polymers had no pronounced impact on the encapsulation efficiency. 


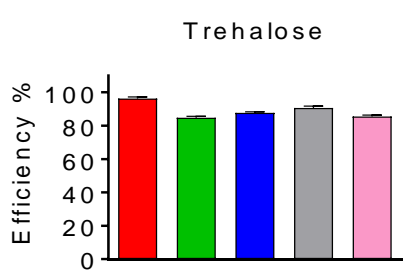

Mannitol

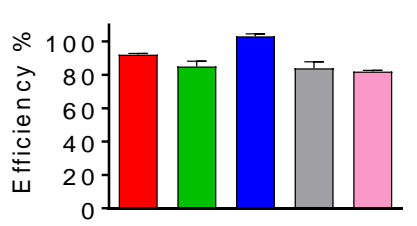

Trehalose + Leucine

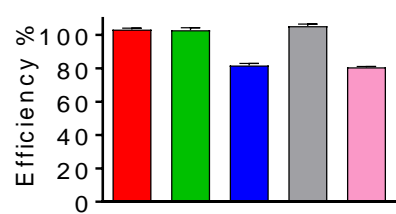

Mannitol + Leucine

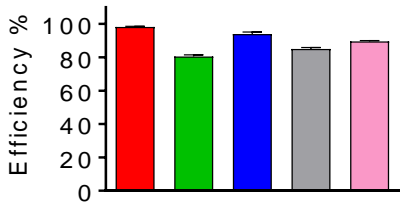

$\square$ uncomplexed lysozyme

$\square\left(\mathrm{mPEG}_{2 \mathrm{k}}-\operatorname{lin}-\mathrm{GA}_{10}\right)$-lysozyme

$\square\left(m P E G_{2 k}-\operatorname{lin}-\mathrm{GA}_{30}\right)$-lysozyme

$\square\left(\mathrm{mPEG}_{2 \mathrm{k}}-\mathrm{mik}-\left(\mathrm{GA}_{10}\right)_{3}\right)$-lysozyme

$\left(m P E G_{2 k}-m i k-\left(G_{30}\right)_{3}\right)$-lysozym e

Figure 3. Protein encapsulation efficiency for dry powder formulations prepared using trehalose (up to $100 \%$ $(w / w)$ ), trehalose (up to $100 \%(w / w))+$ leucine $(10 \%(w / w))$, mannitol (up to $100 \%(w / w)$ ), and mannitol (up to $100 \%(w / w))+$ leucine $(10 \%(w / w))$ as excipients. All formulations also contain $6.6 \%(w / w)$ phosphate buffer salts. All experiments were carried out in quadruplicate.

Differential scanning calorimetry (DSC) analysis was performed to further evaluate the physical properties of the dry powders formulated (Table 2). Amorphous trehalose containing dry powders showed a glass transition temperature $\left(\mathrm{T}_{\mathrm{g}}\right)$ between 124 and $131{ }^{\circ} \mathrm{C}$, indicating these formulations are likely to be stable in normal storage conditions. The values obtained are higher than those reported for dry pure trehalose - e.g. $106^{\circ} \mathrm{C}$ (Roe and Labuza, 2005), and $121{ }^{\circ} \mathrm{C}$ (Grasmeijer et al., 2013) - likely due to the presence of phosphate buffer salts and/or protein-polypeptide complexes in the tested formulations (Ohtake et al., 2004) (Bellavia et al., 2009). In terms of overall stability of tested dry powders, the $\mathrm{T}_{\mathrm{g}}$ of control trehalose formulation is already well above standard storage temperatures, thus the increase in glass transition temperature observed in the presence of buffer salts and/or protein-polypeptide complexes is not likely to result in further significant stabilisation of the formulations.

For crystalline mannitol based dry powders, an endothermic melting transition $\left(T_{m}\right)$ between 148 and $162^{\circ} \mathrm{C}$ typical of crystalline mannitol was observed (Ong et al., 2014; Takada et al., 2009). 
Moisture content was found to be lower than 5\% for all spray dried powders, achieving values in the range of $0.5-2.0 \%$ for mannitol containing dry powders, likely due to their crystalline nature (ESI, Table S2). Such water content is typical of spray-dried protein formulations (Bosquillon et al., 2004) (Balducci et al., 2014; Maury et al., 2005b) and indicates efficient drying of these materials under the selected operating conditions. Low moisture content in dry powders for pulmonary application is a desirable formulation attribute, as residual moisture can lead to an increase in powder cohesiveness or a reduction in the formulation glass transition temperature (Chang and Pikal, 2009).

Table 2. Thermal behavior of dry powders tested in this study.

\begin{tabular}{|c|c|c|c|}
\hline $\begin{array}{c}\text { Excipients } \\
(w / w)\end{array}$ & $\begin{array}{l}\text { Nanocomplexes } \\
(\% w / w)\end{array}$ & $\mathbf{T}_{\mathrm{g}}\left({ }^{\circ} \mathbf{C}\right)$ & $\mathbf{T}_{\mathrm{m}}\left({ }^{\circ} \mathbf{C}\right)$ \\
\hline \multirow[t]{6}{*}{ Up to $100 \%$ Trehalose } & no lysozyme (control) & 130.6 & $-\mathrm{a}^{\mathrm{a}}$ \\
\hline & $5 \%$ Free lysozyme & 127.4 & $-a^{a}$ \\
\hline & $10 \%\left(\mathrm{mPEG}_{2 \mathrm{k}}-\right.$ lin-GA 10$)-$ lysozyme & 128.0 & $-a^{a}$ \\
\hline & $10 \%\left(\mathrm{mPEG}_{2 \mathrm{k}}-\right.$ lin-GA 30$)-$ lysozyme & 125.9 & $-a^{a}$ \\
\hline & $10 \%\left(\mathrm{mPEG}_{2 \mathrm{k}}-m i k-\left(\mathrm{GA}_{10}\right)_{3}\right)-$ lysozyme & 127.0 & $-a^{a}$ \\
\hline & $10 \%\left(\mathrm{mPEG}_{2 \mathrm{k}}-m i k-\left(\mathrm{GA}_{30}\right)_{3}\right)-$ lysozyme & 130.7 & $-a^{a}$ \\
\hline \multirow{6}{*}{$\begin{array}{l}\text { Up to } 100 \% \text { Trehalose } \\
+10 \% \text { Leucine }\end{array}$} & no lysozyme (control) & 128.7 & $-{ }^{\mathrm{a}}$ \\
\hline & $5 \%$ Free lysozyme & 126.4 & $-{ }^{a}$ \\
\hline & $10 \%\left(\mathrm{mPEG}_{2 \mathrm{k}}-\right.$ lin-GA 10$)-$ lysozyme & 124.2 & $-a^{a}$ \\
\hline & $10 \%\left(\mathrm{mPEG}_{2 \mathrm{k}}-\right.$ lin-GA 30$)-$ lysozyme & 126.7 & $-a^{a}$ \\
\hline & $10 \%\left(\mathrm{mPEG}_{2 \mathrm{k}}-m i k-\left(\mathrm{GA}_{10}\right)_{3}\right)-$ lysozyme & 129.2 & $-a^{a}$ \\
\hline & $10 \%\left(\mathrm{mPEG}_{2 \mathrm{k}}-m i k-\left(\mathrm{GA}_{30}\right)_{3}\right)-$ lysozyme & 129.5 & $-a^{a}$ \\
\hline \multirow[t]{4}{*}{ Up to $100 \%$ Mannitol } & no lysozyme (control) & $-{ }^{-b}$ & 162.4 \\
\hline & $5 \%$ Free lysozyme & $-{ }^{b}$ & 159.4 \\
\hline & $10 \%\left(\mathrm{mPEG}_{2 \mathrm{k}}-\right.$ lin-GA 10$)-$ lysozyme & $-b$ & 158.0 \\
\hline & $10 \%\left(\mathrm{mPEG}_{2 \mathrm{k}}-\right.$ lin-GA 30$)-$ lysozyme & $-b$ & 148.6 \\
\hline
\end{tabular}




\begin{tabular}{|c|c|c|c|}
\hline & $10 \%\left(\mathrm{mPEG}_{2 \mathrm{k}}-m i k-\left(\mathrm{GA}_{10}\right)_{3}\right)-$ lysozyme & $-b$ & 159.4 \\
\hline & $10 \%\left(\mathrm{mPEG}_{2 \mathrm{k}}-m i k-\left(\mathrm{GA}_{30}\right)_{3}\right)-$ lysozyme & $-{ }^{b}$ & 159.5 \\
\hline \multirow{6}{*}{$\begin{array}{l}\text { Up to } 100 \% \text { Mannitol } \\
+10 \% \text { Leucine }\end{array}$} & no lysozyme (control) & $-{ }^{b}$ & 160.8 \\
\hline & $5 \%$ Free lysozyme & $-{ }^{b}$ & 158.0 \\
\hline & $10 \%\left(\mathrm{mPEG}_{2 \mathrm{k}}-\right.$ lin-GA $\left.\mathrm{G}_{10}\right)-$ lysozyme & $--^{b}$ & 158.7 \\
\hline & $10 \%\left(\mathrm{mPEG}_{2 \mathrm{k}}-\right.$ lin-GA 30$)$ - lysozyme & $-\mathrm{b}$ & 147.9 \\
\hline & $10 \%\left(\mathrm{mPEG}_{2 \mathrm{k}}-m i k-\left(\mathrm{GA}_{10}\right)_{3}\right)-$ lysozyme & $--^{b}$ & 158.0 \\
\hline & $10 \%\left(\mathrm{mPEG}_{2 \mathrm{k}}-m i k-\left(\mathrm{GA}_{30}\right)_{3}\right)-$ lysozyme & $-{ }^{b}$ & 158.2 \\
\hline
\end{tabular}

All formulations also contained $6.6 \%(w / w)$ phosphate buffer salts. $\mathrm{T}_{\mathrm{g}}$ and $\mathrm{T}_{\mathrm{m}}$ are represented as the average value of two individual measurements.

a c_c indicates that no $\mathrm{T}_{\mathrm{m}}$ was observed; trehalose is amorphous compound; ${ }^{\mathrm{b}}$ “-‘ denotes that no $\mathrm{T}_{\mathrm{g}}$ was observed due to crystalline nature of mannitol.

\subsection{Aerosolisation performance}

In the development of dry powders for pulmonary drug delivery, the Emitted Dose (the percentage of the mass of a formulation exiting a given device after inhalation, ED) and Fine Particle Fraction (the fraction of particles with an aerodynamic diameter below $5 \mu \mathrm{m}$, hence suitable for pulmonary delivery, FPF) are essential formulations attributes. The ED values obtained with the majority of the formulations developed in this study were in the $>80-100 \%$ range. The exceptions were some trehalose containing powders: pure trehalose, the formulation containing uncomplexed protein, and the formulation of ( $\mathrm{mPEG}_{2 \mathrm{k}}$-polyGA $)_{30}$-protein nanocomplexes. These data are not unexpected, as powders with a high content of trehalose have been shown to possess poor aerosolisation properties, attributed to the highly hygroscopic and adhesive nature of amorphous trehalose (Maa et al., 1997).

The trehalose, mannitol and mannitol+leucine containing formulations exhibited a FPF $<40 \%$, while values $>60 \%$ were obtained for the trehalose+leucine dry powders (Figure 4); this could indicate a potential for a high dry powder deposition in the lungs. A large content of mannitol 
has been previously shown to adversely affect the respirable fraction of spray-dried powders, likely a consequence of the formation of particle aggregates (Bosquillon et al., 2001). Leucine improved the aerosolisation performances of powders prepared with both sugars (Figure 4, p $<$ 0.05). This is in line with the general consensus in the literature, where a small proportion of a surface active molecule (e.g. leucine) is believed to be important to improve the dispersability of dry powder particles (Lechuga-Ballesteros et al., 2008; Li et al., 2003; Li et al., 2005; Lucas et al., 1999). It should also be noted that low yields $(<40 \%)$ were obtained following spraydrying of both trehalose and mannitol leucine-free formulations, potentially due to material aggregation and low dispersability. Importantly, the presence of protein nanocomplexes within the formulations did not have a detrimental effect on the aerodynamic properties (ED and FPF) of the most performant dry powders made of trehalose+leucine.

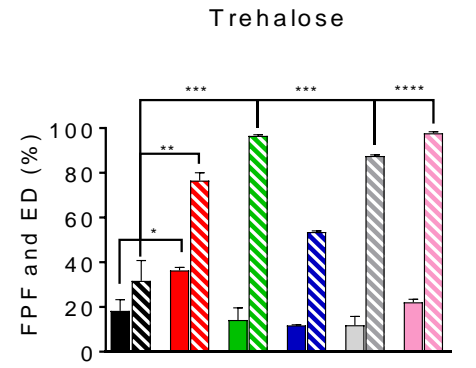

Mannitol

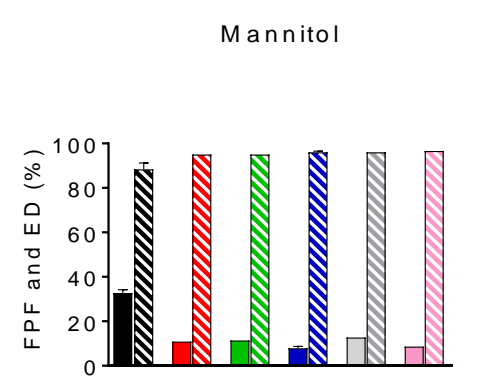

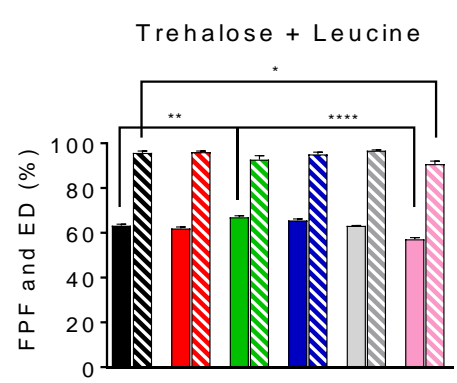

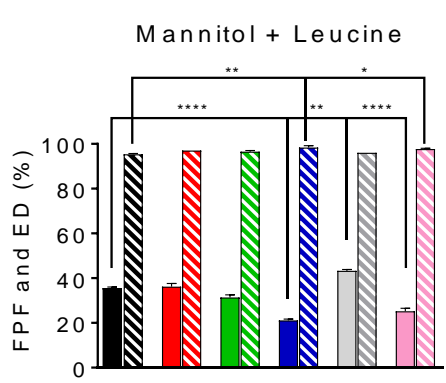

Hatched bars: emitted dose (ED)

Solid bars: Fine particles fraction (FPF)

control

$\square$ uncomplexed lysozyme

$\square\left(m P E G_{2 k}-\operatorname{lin}-G_{A_{10}}\right)$-lysozyme

$\square\left(m P E G_{2 k}-\right.$ lin- $\left.G A_{30}\right)$-lysozyme

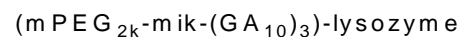

$\left(\mathrm{mPEG} \mathrm{2k}-\mathrm{mik}-\left(\mathrm{GA}_{30}\right)_{3}\right)$-lysozyme

Figure 4. Fine particle fraction (FPF) and emitted dose (ED) of trehalose (up to $100 \%(w / w)$ ); trehalose (up to $100 \%(w / w))+$ leucine $(10 \%(w / w)$ ); mannitol (up to $100 \%(w / w)$ ); and mannitol (up to $100 \%(w / w)$ ) + leucine $(10 \%(w / w))$ dry powders. 'Control' denotes blank powder formulation that contains only excipient(s) without lysozyme or copolymer, and 'uncomplexed lysozyme' denotes dry powder formulation that contains no copolymer. All formulations also contained $6.6 \%(w / w)$ phosphate buffer salts. All experiments were carried out in triplicate. FPF and ED values from mannitol dry powders were obtained from single, double or triple measurements due to low material quantity obtained. One-way ANOVA was used for statistical analysis. $* \mathrm{p}<$ $0.1, * * \mathrm{p}<0.01 * * * \mathrm{p}<0.001, * * * * \mathrm{p}<0.0001$ 


\subsection{Recovery, protein activity and protein protection against proteolytic degradation}

The formulated dry powders ability to 'release' the original polymer-protein nanocomplexes when suspended in an aqueous environment was evaluated by their exposure to $\mathrm{pH} 7.4$ phosphate buffer; the $\mathrm{pH}$ of the airway lining fluid has been reported to be around 7.0 (Jayaraman et al., 2001). Following a 15-minutes incubation, a particle size analysis was conducted on the resulting suspension by nanoparticle tracking analysis (NTA), a method used previously (Dragovic et al., 2011; Nieto-Orellana et al., 2017). The particle size distribution of samples recovered following dispersion of dry powders in the buffer appears to be no significantly different to that for ( $\mathrm{mPEG}_{2 \mathrm{k}}$-polyGA)-lysozyme nanocomplexes before spraydrying (Figure 5). Overall, these data showed that under the conditions chosen for the preparation of these spray-dried formulations, the integrity of the nanocomplexes was not compromised, and that they could be recovered upon dispersion of dry powders in aqueous medium.

No particle size profile could be generated by NTA upon dispersion in the buffer of formulations containing un-complexed lysozyme, or free $\mathrm{mPEG}_{2 \mathrm{k}}$-polyGA polymer, confirming that the nano-sized assemblies measured in the nanocomplexes containing formulations were indeed polymer-protein complexes. 
A

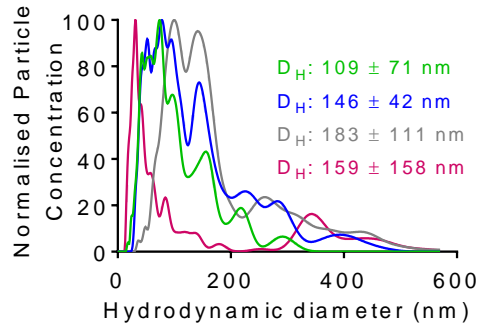

C

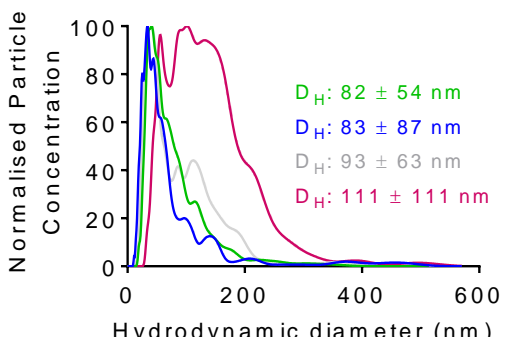

Hydrodynam ic diameter $(\mathrm{nm})$

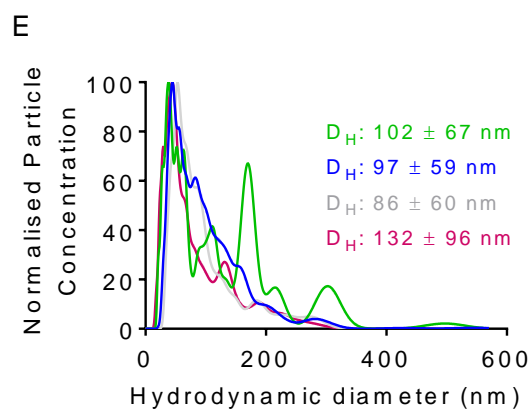

B

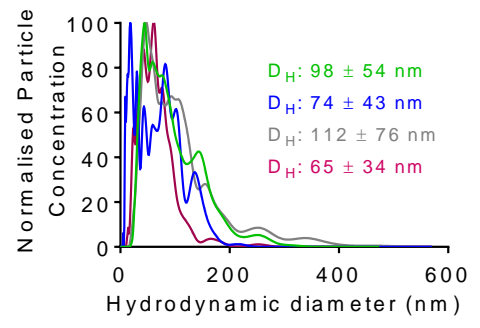

$\mathrm{D}$

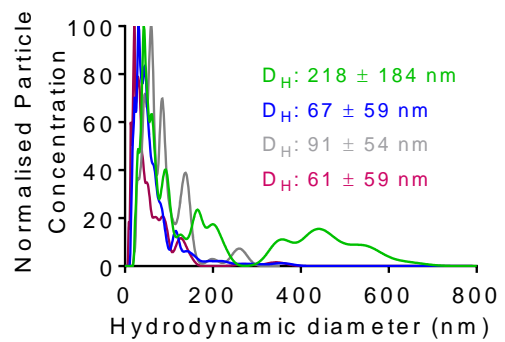

$\square\left(\mathrm{mPEG} 2 \mathrm{k}-\operatorname{lin}-\mathrm{GA}_{10}\right)$-lysozyme

$\square\left(m P E G_{2 k}-l i n-G A_{30}\right)-l y s o z y m e$

$\left(\mathrm{mPE} \mathrm{G}_{2 \mathrm{k}}-\mathrm{mik}-\left(\mathrm{GA}_{10}\right)_{3}\right)$-lysozyme

$\left(m P E G_{2 k}-m i k-\left(A_{30}\right)_{3}\right)$-lysozyme

Figure 5. Particle size (hydrodynamic diameter) as measured by nanoparticle tracking analysis (NTA) of protein$\left(\mathrm{mPEG}_{2 \mathrm{k}}\right.$-polyGA)-lysozyme nanocomplexes before spray-drying (A) and spray-dried powder formulations following incubation in phosphate buffer (PB, $10 \mathrm{mM}, \mathrm{pH} 7.4$ ) at $70 \mu \mathrm{g} \mathrm{mL}$ protein concentration; mannitol+leucine (B), mannitol (C), trehalose+leucine (D), and trehalose (E) containing dry powders.

To evaluate the stability of the protein following spray-drying, enzymatic activity of incorporated lysozyme was evaluated by a turbidimetric assay using Micrococcus lysodeikticus as the substrate. All nanocomplexes recovered from the dry powders following suspension in phosphate buffer exhibited a lower enzymatic activity than un-complexed lysozyme recovered from the corresponding formulation (Figure 6). This was not unexpected, as we previously observed that complexation of lysozyme with $\mathrm{mPEG}_{2 \mathrm{k}}$-polyGA polymers into non-covalent 
complexes profoundly reduced its enzymatic activity (Nieto-Orellana et al., 2017). Although this is not fully elucidated, it is probable that the enzyme active site becomes less accessible to the substrate upon the protein's complexation with the polymers. However, $70-100 \%$ of the lysozyme activity from nanocomplexes could be recovered upon addition of excess of poly(allyl amine); a polycationic polymer which sequesters polyanionic polymers (Tomita et al., 2010) such as poly(glutamic acid) block of ( $\mathrm{mPEG}_{2 \mathrm{k}}$-polyGA) copolymers, inducing complex disassembly and release of the 'free' lysozyme (Figure 6). Poly(allyl amine) was employed here as a tool to recover lysozyme from ionic polymer-protein complexes and assess its residual enzymatic activity, in analogy to previous studies by Shiraki and co-workers (Kurinomaru et al., 2014; Kurinomaru et al., 2012; Tomita et al., 2010). Whilst further studies on in vivo release kinetics are needed, these results suggest that the release of protein from nanocomplexes could occur in a 'competitive dissociation conditions' - e.g. the presence of charged species or local differences in $\mathrm{pH}$ and ionic strength.

Interestingly, it appears that complexation with $\mathrm{mPEG}_{2 \mathrm{k}}$-polyGA copolymers, especially $\mathrm{mPEG}_{2 \mathrm{k}}$-lin- $\mathrm{GA}_{30}$ in mannitol+leucine dry powder formulations, could provide protection against lysozyme partial loss of activity following production of the dry powders formulations (Figure 6). However at this stage, due to the observed high preservation of 'free' lysozyme's enzymatic activity on processing under described spray-drying conditions, we cannot confidently confirm whether the complexation with the $\mathrm{mPEG}_{2 \mathrm{k}}$-polyGA copolymers indeed protects stability and biological activity of the complexed protein. The protective potential of the copolymers investigated in this study should be tested using biologicals shown to be prone to degradation upon spray-drying and/or mannitol crystallization, such as $\beta$-galactosidase or alcohol dehydrogenase (Estevinho et al., 2015; Shiga et al., 2014), and will be the subject of future communications. 

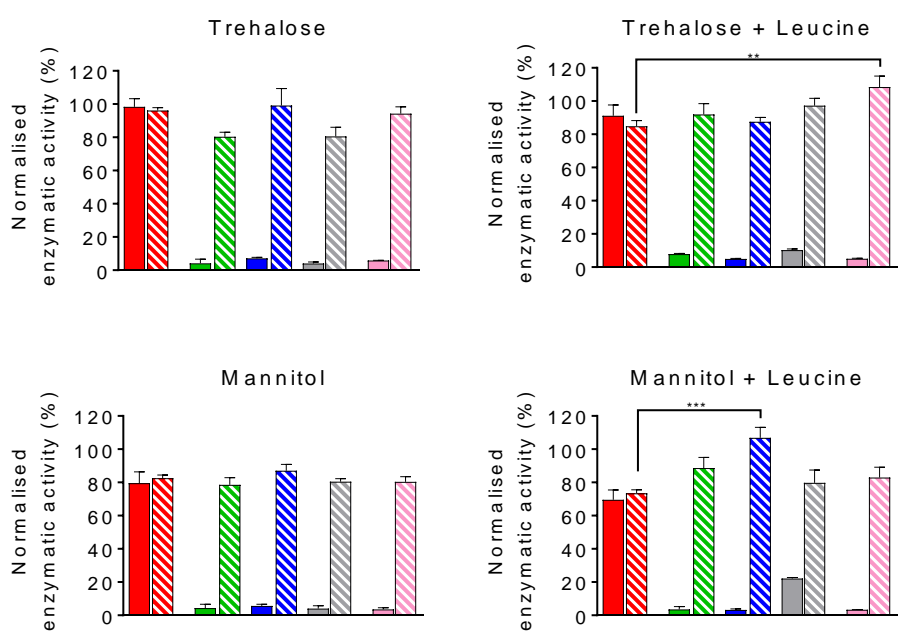

Solid bars: lysozyme activity following

incubation of dry powders in $P B$

Hatched bars: lysozyme activity following incubation of dry powders in $P B$

in presence of poly (allyl amine)

uncomplexed lysozyme

$\square\left(m P E G_{2 k}-\right.$ lin- $\mathrm{A}_{10}$ )-lysozyme

$\square\left(m P E G_{2 k}-\right.$ lin- $\left.\mathrm{AA}_{30}\right)$-lysozyme

$\left(m P E G_{2 k}-m i k-\left(\mathrm{GA}_{10}\right)_{3}\right)$-lysozyme

$\left(m P E G_{2 k}-m i k-\left(\mathrm{GA}_{30}\right)_{3}\right)$-lysozyme

Figure 6. Lysozyme enzymatic activity. Trehalose, trehalose+leucine, mannitol and mannitol+leucine dry powders investigated in this study. 'Un-complexed lysozyme' is a dry powder formulation that contains lysozyme only, with no copolymer added. All experiments were carried out in triplicate. Un-complexed free lysozyme was used as a reference (100\% enzymatic activity). One-way ANOVA was used for statistical analysis. $*$ p $<0.1, * *$ $\mathrm{p}<0.01 * * * \mathrm{p}<0.001, * * * * \mathrm{p}<0.0001$.

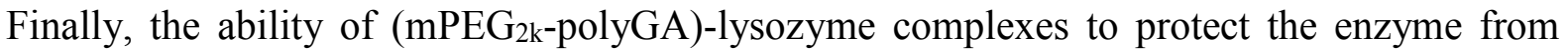
proteolytic degradation was assessed. A selection of peptidases has been found in the lung of humans and other mammalians, including cathepsin B, collagenase, elastase chymotrypsin, aminopeptidase P, neutrophil proteases and a range of carboxypeptidases (Fujita et al., 1990; Janoff et al., 1983; Orlowski et al., 1981; Stratford and Lee, 1986; Wall and Lanutti, 1993). In this study trypsin, which exclusively cleaves arginine and lysine residues at the protein Cterminal end (Olsen et al., 2004), was employed as a model proteolytic enzyme capable of degrading lysozyme, but not the mPEG2k-polyGA copolymers (which do not possess Arg or Lys residues), which simplified the interpretation of experimental results. 
The nanocomplexes were exposed to trypsin for 3 hours, under conditions previously shown to be sufficient for the enzyme to degrade lysozyme and then be auto-digested (Fraser and Powell, 1950). Following the incubation with enzyme, poly(allyl amine) was added with the aim to release lysozyme from the ( $\mathrm{mPEG}_{2 \mathrm{k}}$-polyGA) nanocomplexes. When not complexed with the copolymers, lysozyme activity was in the present study reduced to less than $40 \%$ of its initial value (Figure 7). Non-covalent complexation with $\mathrm{mPEG}_{2 \mathrm{k}}$-polyGA copolymers tested was able to provide protection to complexed lysozyme against enzymatic degradation, whereby $\mathrm{mPEG}_{2 \mathrm{k}}$-lin-GA 30 appears to be the most efficient. This is in agreement with our previous studies that demonstrated superior ability this copolymer to complex lysozyme, compared to the other members of this polymer library (Nieto-Orellana et al., 2017).
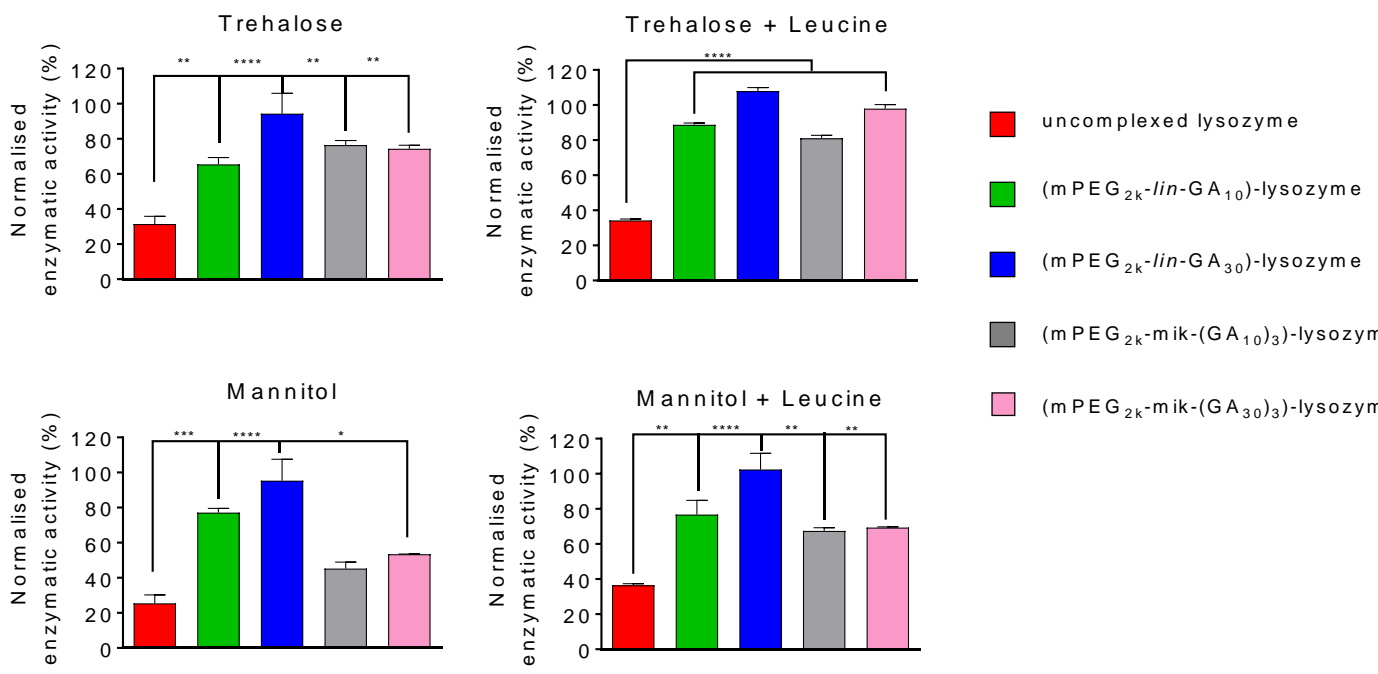

$\square\left(\mathrm{mPEG}_{2 \mathrm{k}}-\mathrm{mik}-\left(\mathrm{GA}_{10}\right)_{3}\right)$-lysozyme

$\square\left(\mathrm{mPEG}_{2 \mathrm{k}}-\mathrm{mik}-\left(\mathrm{GA}_{30}\right)_{3}\right)$-lysozyme

Figure 7. (mPEG $2 \mathrm{k}$-polyGA)-lysozyme complexes: protection against lysozyme proteolytic degradation. Lysozyme activity was measured after incubation of the dry powders in the presence of trypsin for $3 \mathrm{~h}$, followed by treatment with poly(allyl amine) for $1 \mathrm{~h}$. Trehalose, trehalose+leucine, mannitol and mannitol+leucine dry powders were investigated in this study. All experiments were carried out in triplicate. Un-complexed free lysozyme was used as a reference (100\% enzymatic activity). One-way ANOVA was used for statistical analysis. $* \mathrm{p}<0.1, * * \mathrm{p}<0.01 * * * \mathrm{p}<0.001, * * * * \mathrm{p}<0.0001$.

\section{Conclusions}


In the present study we demonstrated that a non-covalent protein complexes with $\mathrm{mPEG}_{2 \mathrm{k}-}$ polyGA copolymers, with either linear or miktoarm architecture, can be successfully formulated into spray-dried powders with product attributes appropriate for inhalation delivery. Typical inhalable aerosol excipients such as trehalose, mannitol and leucine were employed in the production, whereby the presence of leucine was found to be critical in obtaining a dry powder with spherical shape and particle size $\left(\mathrm{D}_{50} \sim 2.5 \mu \mathrm{m}\right)$ optimal for inhalation. The moisture content was found to be between $0.5-5.0 \%$, a range appropriate for the stability of protein formulations. The best aerodynamic properties were observed for dry powders composed of trehalose+leucine+polymer-protein nanocomplexes, with FPFs as high as 68\%, without any significant negative effect of nanocomplexes on powder properties. 'Original' protein-polymer nanocomplexes could be recovered from dry powder formulations, with protein retaining its enzymatic activity, especially when $\mathrm{mPEG}_{2 \mathrm{k}}$-lin-GA 30 copolymer was employed in the complexation. The same copolymer also provided the best protection to the complexed protein against enzymatic degradation. Hence, dry powder formulations incorporating non-covalent polymer-protein nanocomplexes have attributes appropriate for efficient and protective inhalation delivery of proteins.

\section{ACKNOWLEDGMENT}

Vectura Group plc and the School of Pharmacy at the University of Nottingham are acknowledged for funding A. Nieto-Orellana's $\mathrm{PhD}$ studentship.

Nanoscale \& Microscale Research Centre (NMRC) is acknowledged for providing the facilities for NTA analysis.

\section{REFERENCES}

Adler, M., Lee, G., 1999. Stability and surface activity of lactate dehydrogenase in spraydried trehalose. J. Pharm. Sci. 88, 199-208. 
Armstrong, D.J., Elliott, P.N., Ford, J.L., Gadsdon, D., McCarthy, G.P., Rostron, C., Worsley, M.D., 1996. Poly-(D,L-lactic acid) microspheres incorporating histological dyes for intra-pulmonary histopathological investigations. J. Pharm. Pharmacol. 48, 258-262.

Bailey, M.M., Berkland, C.J., 2009. Nanoparticle formulations in pulmonary drug delivery. Med. Res. Rev. 29, 196-212.

Bakaltcheva, I., O'Sullivan, A.M., Hmel, P., Ogbu, H., 2007. Freeze-dried whole plasma: Evaluating sucrose, trehalose, sorbitol, mannitol and glycine as stabilizers. Thromb. Res. 120, 105-116.

Balducci, A.G., Cagnani, S., Sonvico, F., Rossi, A., Barata, P., Colombo, G., Colombo, P., Buttini, F., 2014. Pure insulin highly respirable powders for inhalation. Eur. J. Pharm. Sci. 51, 110-117.

Bellavia, G., Cottone, G., Giuffrida, S., Cupane, A., Cordone, L., 2009. Thermal Denaturation of Myoglobin in Water-Disaccharide Matrixes: Relation with the Glass Transition of the System. The Journal of Physical Chemistry B 113, 11543-11549.

Bosquillon, C., Lombry, C., Préat, V., Vanbever, R., 2001. Influence of formulation excipients and physical characteristics of inhalation dry powders on their aerosolization performance. J. Controlled Release 70, 329-339.

Bosquillon, C., Préat, V., Vanbever, R., 2004. Pulmonary delivery of growth hormone using dry powders and visualization of its local fate in rats. J. Controlled Release 96, 233-244.

Carvalho, T.C., Peters, J.I., Williams, R.O., 3rd, 2011. Influence of particle size on regional lung deposition--what evidence is there? Int. J. Pharm. 406, 1-10.

Chang, L.L., Pikal, M.J., 2009. Mechanisms of protein stabilization in the solid state. J. Pharm. Sci. 98, 2886-2908.

Dailey, L.A., Schmehl, T., Gessler, T., Wittmar, M., Grimminger, F., Seeger, W., Kissel, T., 2003. Nebulization of biodegradable nanoparticles: impact of nebulizer technology and nanoparticle characteristics on aerosol features. J. Control. Release 86, 131-144.

Depreter, F., Pilcer, G., Amighi, K., 2013. Inhaled proteins: challenges and perspectives. Int. J. Pharm. 447, 251-280.

Dragovic, R.A., Gardiner, C., Brooks, A.S., Tannetta, D.S., Ferguson, D.J., Hole, P., Carr, B., Redman, C.W., Harris, A.L., Dobson, P.J., Harrison, P., Sargent, I.L., 2011. Sizing and phenotyping of cellular vesicles using Nanoparticle Tracking Analysis. Nanomedicine 7, 780788.

Dunne, M., Corrigan, O.I., Ramtoola, Z., 2000. Influence of particle size and dissolution conditions on the degradation properties of polylactide-co-glycolide particles. Biomaterials 21, 1659-1668.

Estevinho, B.N., Ramos, I., Rocha, F., 2015. Effect of the $\mathrm{pH}$ in the formation of $\beta$ galactosidase microparticles produced by a spray-drying process. Int. J. Biol. Macromol. 78, 238-242.

Fowler, R., Vllasaliu, D., Falcone, F.H., Garnett, M., Smith, B., Horsley, H., Alexander, C., Stolnik, S., 2013a. Uptake and transport of B(12)-conjugated nanoparticles in airway epithelium. J. Controlled Release 172, 374-381.

Fowler, R., Vllasaliu, D., Trillo, F.F., Garnett, M., Alexander, C., Horsley, H., Smith, B., Whitcombe, I., Eaton, M., Stolnik, S., 2013b. Nanoparticle transport in epithelial cells: pathway switching through bioconjugation. Small 9, 3282-3294. 
Fraser, D., Powell, R.E., 1950. The kinetics of trypsin digestion. J. Biol. Chem. 187, 803-820.

Fujita, J., Nelson, N.L., Daughton, D.M., Dobry, C.A., Spurzem, J.R., Irino, S., Rennard, S.I., 1990. Evaluation of elastase and antielastase balance in patients with chronic bronchitis and pulmonary emphysema. Am. Rev. Respir. Dis. 142, 57-62.

Garcia-Verdugo, I., Descamps, D., Chignard, M., Touqui, L., Sallenave, J.-M., 2010. Lung protease/anti-protease network and modulation of mucus production and surfactant activity. Biochimie 92, 1608-1617.

Grasmeijer, N., Stankovic, M., de Waard, H., Frijlink, H.W., Hinrichs, W.L.J., 2013. Unraveling protein stabilization mechanisms: Vitrification and water replacement in a glass transition temperature controlled system. Biochim. Biophys. Acta 1834, 763-769.

Gursahani, H., Riggs-Sauthier, J., Pfeiffer, J., Lechuga-Ballesteros, D., Fishburn, C.S., 2009. Absorption of Polyethylene Glycol (PEG) Polymers: The Effect of PEG Size on Permeability. J. Pharm. Sci. 98, 2847-2856.

Haque, M.A., Adhikari, B., 2015. Proteins in Spray Drying Process, in: Mujumdar, A.S. (Ed.), Handbook of Industrial Drying - Fourth Edition. CRC Press, pp. 971-983.

Heidtmann, H.-H., Salge, U., Abrahamson, M., Bencina, M., Kastelic, L., Kopitar-Jerala, N., Turk, V., Lah, T.T., 1997. Cathepsin B and cysteine proteinase inhibitors in human lung cancer cell lines. Clin. Exp. Metastasis 15, 368-381.

Hulse, W.L., Forbes, R.T., Bonner, M.C., Getrost, M., 2008. Do co-spray dried excipients offer better lysozyme stabilisation than single excipients? Eur. J. Pharm. Sci. 33, 294-305.

Hussain, A., Arnold, J.J., Khan, M.A., Ahsan, F., 2004. Absorption enhancers in pulmonary protein delivery. J. Control. Release 94, 15-24.

Islam, M.I.U., Langrish, T.A.G., 2010. An investigation into lactose crystallization under high temperature conditions during spray drying. Food Res. Int. 43, 46-56.

Janoff, A., Raju, L., Dearing, R., 1983. Levels of elastase activity in bronchoalveolar lavage fluids of healthy smokers and nonsmokers. Am. Rev. Respir. Dis. 127, 540-544.

Jarvis, S., Ind, P.W., Thomas, C., Goonesekera, S., Haffenden, R., Abdolrasouli, A., Fiorentino, F., Shiner, R.J., 2014. Microbial contamination of domiciliary nebulisers and clinical implications in chronic obstructive pulmonary disease. BMJ Open Respiratory Research 1.

Jayaraman, S., Song, Y., Vetrivel, L., Shankar, L., Verkman, A.S., 2001. Noninvasive in vivo fluorescence measurement of airway-surface liquid depth, salt concentration, and $\mathrm{pH}$. J. Clin. Invest. 107, 317-324.

Jin, T.H., Tsao, E., Goudsmit, J., Dheenadhaylan, V., Sadoff, J., 2010. Stabilizing formulations for inhalable powders of an adenovirus 35-vectored tuberculosis (TB) vaccine (AERAS-402). Vaccine 28, 4369-4375.

Kibbe, A.H., Association, A.P., 2000. Handbook of Pharmaceutical Excipients. American Pharmaceutical Association.

Klingler, C., Muller, B.W., Steckel, H., 2009. Insulin-micro- and nanoparticles for pulmonary delivery. Int. J. Pharm. 377, 173-179.

Křepela, E., Procházka, J., Mynaříková, H., Kárová, B., Polák, J., Čermák, J., Roubková, H., 1995. Multiple forms of cathepsin b in human lung cancer. Int. J. Cancer 61, 44-53. 
Kurinomaru, T., Tomita, S., Hagihara, Y., Shiraki, K., 2014. Enzyme Hyperactivation System Based on a Complementary Charged Pair of Polyelectrolytes and Substrates. Langmuir 30, 3826-3831.

Kurinomaru, T., Tomita, S., Kudo, S., Ganguli, S., Nagasaki, Y., Shiraki, K., 2012. Improved Complementary Polymer Pair System: Switching for Enzyme Activity by PEGylated Polymers. Langmuir 28, 4334-4338.

Labiris, N.R., Dolovich, M.B., 2003. Pulmonary drug delivery. Part II: The role of inhalant delivery devices and drug formulations in therapeutic effectiveness of aerosolized medications. Br. J. Clin. Pharmacol. 56, 600-612.

Lechuga-Ballesteros, D., Charan, C., Stults, C.L., Stevenson, C.L., Miller, D.P., Vehring, R., Tep, V., Kuo, M.C., 2008. Trileucine improves aerosol performance and stability of spraydried powders for inhalation. J. Pharm. Sci. 97, 287-302.

Li, H.Y., Neill, H., Innocent, R., Seville, P., Williamson, I., Birchall, J.C., 2003. Enhanced dispersibility and deposition of spray-dried powders for pulmonary gene therapy. J. Drug Target. 11, 425-432.

Li, H.Y., Seville, P.C., Williamson, I.J., Birchall, J.C., 2005. The use of amino acids to enhance the aerosolisation of spray-dried powders for pulmonary gene therapy. J. Gene Med. $7,343-353$.

Littringer, E.M., Mescher, A., Eckhard, S., Schröttner, H., Langes, C., Fries, M., Griesser, U., Walzel, P., Urbanetz, N.A., 2012a. Spray Drying of Mannitol as a Drug Carrier-The Impact of Process Parameters on Product Properties. Drying Technol. 30, 114-124.

Littringer, E.M., Mescher, A., Schroettner, H., Achelis, L., Walzel, P., Urbanetz, N.A., 2012b. Spray dried mannitol carrier particles with tailored surface properties--the influence of carrier surface roughness and shape. Eur. J. Pharm. Biopharm. 82, 194-204.

Lucas, P., Anderson, K., Potter, U.J., Staniforth, J.N., 1999. Enhancement of Small Particle Size Dry Powder Aerosol Formulations using an Ultra Low Density Additive. Pharm. Res. $16,1643-1647$.

Maa, Y.F., Costantino, H.R., Nguyen, P.A., Hsu, C.C., 1997. The effect of operating and formulation variables on the morphology of spray-dried protein particles. Pharm. Dev.

Technol. 2, 213-223.

Malik, D.K., Baboota, S., Ahuja, A., Hasan, S., Ali, J., 2007. Recent advances in protein and peptide drug delivery systems. Curr Drug Deliv 4, 141-151.

Maltesen, M.J., Bjerregaard, S., Hovgaard, L., Havelund, S., van de Weert, M., 2008. Quality by design - Spray drying of insulin intended for inhalation. Eur. J. Pharm. Biopharm. 70, 828838.

Masuda, T., Ide, N., Kitabatake, N., 2005. Structure-Sweetness Relationship in Egg White Lysozyme: Role of Lysine and Arginine Residues on the Elicitation of Lysozyme Sweetness. Chem. Senses 30, 667-681.

Maury, M., Murphy, K., Kumar, S., Mauerer, A., Lee, G., 2005a. Spray-drying of proteins: effects of sorbitol and trehalose on aggregation and FT-IR amide I spectrum of an immunoglobulin G. Eur. J. Pharm. Biopharm. 59, 251-261.

Maury, M., Murphy, K., Kumar, S., Shi, L., Lee, G., 2005b. Effects of process variables on the powder yield of spray-dried trehalose on a laboratory spray-dryer. Eur. J. Pharm.

Biopharm. 59, 565-573. 
Melancon, M.P., Wang, W., Wang, Y., Shao, R., Ji, X., Gelovani, J.G., Li, C., 2007. A Novel Method for Imaging In Vivo Degradation of Poly(L-Glutamic Acid), a Biodegradable Drug Carrier. Pharm. Res. 24, 1217-1224.

Nieto-Orellana, A., Di Antonio, M., Conte, C., Falcone, F.H., Bosquillon, C., Childerhouse, N., Mantovani, G., Stolnik, S., 2017. Effect of polymer topology on non-covalent polymerprotein complexation: miktoarm versus linear mPEG-poly(glutamic acid) copolymers. Polymer Chemistry 8, 2210-2220.

Niven, R.W., 1995. Delivery of biotherapeutics by inhalation aerosol. Crit. Rev. Ther. Drug Carrier Syst. 12, 151-231.

Nyambura, B.K., Kellaway, I.W., Taylor, K.M.G., 2009. Insulin nanoparticles: Stability and aerosolization from pressurized metered dose inhalers. Int. J. Pharm. 375, 114-122.

Ogain, O.N., Li, J., Tajber, L., Corrigan, O.I., Healy, A.M., 2011. Particle engineering of materials for oral inhalation by dry powder inhalers. I-Particles of sugar excipients (trehalose and raffinose) for protein delivery. Int. J. Pharm. 405, 23-35.

Ohtake, S., Schebor, C., Palecek, S.P., de Pablo, J.J., 2004. Effect of pH, counter ion, and phosphate concentration on the glass transition temperature of freeze-dried sugar-phosphate mixtures. Pharm. Res. 21, 1615-1621.

Okudela, K., Mitsui, H., Woo, T., Arai, H., Suzuki, T., Matsumura, M., Kojima, Y., Umeda, S., Tateishi, Y., Masuda, M., Ohashi, K., 2016. Alterations in cathepsin L expression in lung cancers. Pathol. Int. 66, 386-392.

Olsen, J.V., Ong, S.-E., Mann, M., 2004. Trypsin Cleaves Exclusively C-terminal to Arginine and Lysine Residues. Mol. Cell. Proteomics 3, 608-614.

Ong, H.X., Traini, D., Ballerin, G., Morgan, L., Buddle, L., Scalia, S., Young, P.M., 2014. Combined Inhaled Salbutamol and Mannitol Therapy for Mucus Hyper-secretion in Pulmonary Diseases. The AAPS Journal 16, 269-280.

Orlowski, M., Orlowski, J., Lesser, M., Kilburn, K.H., 1981. Proteolytic enzymes in bronchopulmonary lavage fluids: cathepsin B-like activity and prolyl endopeptidase. J. Lab. Clin. Med. 97, 467-476.

Palazzo, F., Giovagnoli, S., Schoubben, A., Blasi, P., Rossi, C., Ricci, M., 2013. Development of a spray-drying method for the formulation of respirable microparticles containing ofloxacin-palladium complex. Int. J. Pharm. 440, 273-282.

Park, S.-H., Kwon, J.-H., Lim, S.-H., Park, H.W., Kim, C.-W., 2007. Characterization of human insulin microcrystals and their absorption enhancement by protease inhibitors in rat lungs. Int. J. Pharm. 339, 205-212.

Pilcer, G., Wauthoz, N., Amighi, K., 2012. Lactose characteristics and the generation of the aerosol. Adv Drug Deliv Rev 64, 233-256.

Roe, K.D., Labuza, T.P., 2005. Glass Transition and Crystallization of Amorphous Trehalose-sucrose Mixtures. Int. J. Food Prop. 8, 559-574.

Scheuch, G., Kohlhaeufl, M.J., Brand, P., Siekmeier, R., 2006. Clinical perspectives on pulmonary systemic and macromolecular delivery. Adv Drug Deliv Rev 58, 996-1008.

Schüle, S., Frieß, W., Bechtold-Peters, K., Garidel, P., 2007. Conformational analysis of protein secondary structure during spray-drying of antibody/mannitol formulations. Eur. J. Pharm. Biopharm. 65, 1-9. 
Shiga, H., Joreau, H., Neoh, L.T., Furuta, T., Yoshii, H., 2014. Encapsulation of Alcohol Dehydrogenase in Mannitol by Spray Drying. Pharmaceutics 6.

Sivadas, N., O'Rourke, D., Tobin, A., Buckley, V., Ramtoola, Z., Kelly, J.G., Hickey, A.J., Cryan, S.A., 2008. A comparative study of a range of polymeric microspheres as potential carriers for the inhalation of proteins. Int. J. Pharm. 358, 159-167.

Soppimath, K.S., Aminabhavi, T.M., Kulkarni, A.R., Rudzinski, W.E., 2001. Biodegradable polymeric nanoparticles as drug delivery devices. J. Control. Release 70, 1-20.

Stratford, R.E., Lee, V.H.L., 1986. Aminopeptidase activity in homogenates of various absorptive mucosae $\mathrm{m}$ the albino rabbit: implications in peptide delivery. Int. J. Pharm. 30, 73-82.

Sung, J.C., Pulliam, B.L., Edwards, D.A., 2007. Nanoparticles for drug delivery to the lungs. Trends Biotechnol. 25, 563-570.

Takada, A., Nail, S.L., Yonese, M., 2009. Influence of ethanol on physical state of freezedried mannitol. Pharm. Res. 26, 1112-1120.

Tomita, S., Ito, L., Yamaguchi, H., Konishi, G.-i., Nagasaki, Y., Shiraki, K., 2010. Enzyme switch by complementary polymer pair system (CPPS). Soft Matter 6, 5320-5326.

Torrado, S., Torrado, S., 2002. Characterization of physical state of mannitol after freezedrying: effect of acetylsalicylic acid as a second crystalline cosolute. Chem. Pharm. Bull. (Tokyo) 50, 567-570.

Tzannis, S.T., Prestrelski, S.J., 1999. Activity-stability considerations of trypsinogen during spray drying: Effects of sucrose. J. Pharm. Sci. 88, 351-359.

Umashankar, M.S., Sachdeva, R.K., Gulati, M., 2010. Aquasomes: a promising carrier for peptides and protein delivery. Nanomedicine 6, 419-426.

Vehring, R., 2008. Pharmaceutical Particle Engineering via Spray Drying. Pharm. Res. 25, 999-1022.

Wall, D.A., Lanutti, A.T., 1993. High levels of exopeptidase activity are present in rat and canine bronchoalveolar lavage fluid. Int. J. Pharm. 97, 171-181.

Weers, J.G., Tarara, T.E., Clark, A.R., 2007. Design of fine particles for pulmonary drug delivery. Expert Opin Drug Deliv 4, 297-313.

Werle, B., Ebert, W., Klein, W., Spiess, E., 1994. Cathepsin B in tumors, normal tissue and isolated cells from the human lung. Anticancer Res. 14, 1169-1176.

Wetter, L.R., Deutsch, H.F., 1951. Immunological studies on egg white proteins. IV. Immunochemical and physical studies of lysozyme. J. Biol. Chem. 192, 237-242.

You, Y., Zhao, M., Liu, G., Tang, X., 2007. Physical characteristics and aerosolization performance of insulin dry powders for inhalation prepared by a spray drying method. $\mathrm{J}$. Pharm. Pharmacol. 59, 927-934. 